\title{
Azul profundo como embriologia cinematográfica e obliquação diagramática
}

Deep Blue as cinematic embryology and diagrammatic obliquation

Sebastian Wiedemann*

Resumo: Partindo da fabulação especulativa Azul Profundo, procuramos explorar neste texto as potencialidades pedagógicas implicadas nesta experimentação conceitual e cinematográfica a partir do dispositivo da "imagem-ovo", como gesto de desaceleração dos processos de criação em favor de outras vidas, sempre menores que operam como modos de existência transitivos e processuais contra - espetáculo. Isto é, modos de experiência cinematográficos que através da "imagem-ovo" dão lugar a uma embriologia cinematográfica como obliquação diagramática de uma pedagogia radical. Disposições que afirmam maneiras outras de entrarmos em relação com as imagens e de estarmos em estado de coaprendizagem constante e impessoal com elas.

Palavras-chave: modos de experiência cinematográficos; ovos cinematográficos; pedagogia radical; aprendizagens mais do que humanas.

\begin{abstract}
Starting from the speculative fabulation Deep Blue, we aim to explore in this text the pedagogical potentialities implied in this conceptual and cinematic experimentation from the dispositif of the "image-egg", as a gesture of slowdown of the processes of creation in favor of other, ever minor lives that operate as transitive and processual modes of existence against the spectacle. In other words, cinematic modes of experience that through the "image-egg" give way to a cinematic embryology as a diagrammatic obliquation of a radical pedagogy. Dispositions that affirm other ways of entering into relation with images and of being in a state of constant and impersonal co-learning with them.
\end{abstract}

Keywords: cinematic modes of experience; cinematic eggs; radical pedagogy; more-than-human learning.
Este é um artigo publicado em acesso aberto (Open Access) sob a licença Creative Commons Attribution, que permite uso, distribuição e reprodução em qualquer meio, sem restrições desde que sem fins comerciais e que o trabalho original seja corretamente citado.

\footnotetext{
* Cineasta-pesquisador e filosofo, Doutor em Educação (Práticas Artísticas, Aprendizagem e Filosofia) pela UNICAMP. Professor-pesquisador da Escola de Educação e Pedagogia da Universidade Pontifícia Bolivariana - Colômbia. Fundador e curador da plataforma Hambre | espacio cine experimental. Mais recentemente publicou o livro "Deep Blue: Future Memories of A Livings Cinematic In-Between" (2019). E-mail: wiedemann.sebastian@gmail.com
} 


\section{Primeira aproximação}

Fazer nascer, ser testemunha do desabrochar da vida. Vida que se diz em infinitas direções e dimensões. Vida que como fluxo não pode ser retida. Ter apego por ela é não se apegar a seus modos de aparecer que sempre são passageiros, que sempre são transições. O Azul profundo, mais uma transição que deve ser levada a seu limite. Não há como atingir um estado essencial deste cenário e fabulação especulativa. Não há como "ser", pois só se "passa" estando à altura das demandas e obrigações que como praticantes desta ecologia de práticas $^{1}$ temos diante do ponto de vista da criação que pede para sempre continuar por outros meios e, portanto, em meio a outras superfícies e conglomerados de afetos.

O Azul profundo como proposição de desapego, de recusa, para justamente estar sempre à altura de outrem, essa atmosfera intersticial da qual o novo emerge. $O$ Azul profundo, no seu cromatismo intensivo, pedindo para desabrochar tonalidades impensadas do pensamento, pedindo para cintilar para além de seu próprio azular. A própria ecologia de modos de experiência cinematográficos pedindo para ser renovada e alargada e como cinema do processo para, de repente, também se dizer gesto pedagógico. Gesto de fazer transbordar as aprendizagens mais do que humanas, como a radicalidade de fazer migrante e nômade a potência que - Azul profundo transporta. Quer dizer que a maior radicalidade ética e política do Azul profundo é se abrir a um devirpolinizador $^{2}$ oceânico, que insiste em fazer do mundo uma nascença incessante e da imagem algo sempre por vir. Eficácia de uma performance cosmopolítica ${ }^{3}$ coletiva, como gesto de pedagogia radical, que por sua vez se diz hospitalidade diante do desconhecido.

Assim, desde a perspectiva de um vitalismo como pragmatismo especulativo e experimental, há de se perguntar pelas consequências, pelos desdobramentos do Azul profundo, quando, de repente, é chamado a comparecer (a-par-comoutros-ser) como gesto de uma pedagogia radical. Ou se se quer da incorporação de hábitos que tornem os corpos, como complexos de relações, mais generativos, mais potentes. Potência esta, que se faria presente no cultivo de gestos de uma embriologia cinematográfica que como veremos, talvez fosse melhor chamar de teratologia, pois nascer como continuação da vida sempre é o advento do novo como uma mutação ou aberração na dobra exterior do ponto de vista da criação. Falamos de insistir em pensar a matéria desde uma disposição generativa e ativa e de modular o Azul profundo como uma proposição pedagógica orientada ao cuidado e ativação dos possíveis. Pois nos tempos das catástrofes ${ }^{4}$ que vivemos há um empobrecimento e uma extinção avassaladora dos processos de criação, que não se dizem só artísticos, mas, sobretudo, cosmológicos; que podem passar pelo humano, mas não só e onde portanto o estético e cosmogenético não param de se confundir.

Se no meio da asfixia se pode respirar um pouco, então como gesto de uma ética do cuidado cabe se dispor a contribuir

\footnotetext{
1 STENGERS, Introductory notes on an ecology of practices.

2 PELBART, $O$ avesso do niilismo.

3 STENGERS, A proposição cosmopolítica.

${ }^{4}$ STENGERS, No tempo das catástrofes.
} 
para que outros também possam respirar. Distribuir a potência! Existir é fazer existir! Talvez, não seja suficiente com ter a prática de respirar em tom azulante, mas já é um começo que diz de um esforço por não sair de um estado de experiência pura ${ }^{5}$ com o mundo e que é a marca de um risco encarnado que pode habilitar o encontro e o halo de confiança necessário para acompanhar o outro (seja este humano ou não) na sua própria tentativa e aventura de ativar os possíveis desde uma posição e perspectiva singular. Tudo e todos, em alguma medida, somos ditos pelo Azul profundo, ou por qualquer outro atractor de afetação, como operadores criativos que dão vazão e diferenciadora atualização ao ponto de vista da criação. Isto é, tudo e todos, humanos e mais do que humanos, como posições relacionais povoáveis por impensadas forças que nos fazem holobiontes e simbiontes especulativos; se dizem guardiões do diferencial na medida em que também são expressão de um acompanhamento dos processos de criação. $O$ gesto pedagógico tornaria explicita esta condição e o curandeiroeducador (função dinâmica que pode se estacionar num "quem" humano ou mais do que humano), sem nenhum privilégio ou hierarquia, seria aquele que insiste em sintonizar e escutar os canais pelos quais as propensões do ponto de vista da criação podem continuar. Polinizar, fazer passar um (im)pulso, que não se sabe muito bem de onde vem e aonde pode ir e que constantemente sussurra, enquanto se subtrai: você é potente, você pode, você é capaz. Este sussurro sempre é pronunciado de modo oblíquo, e às vezes é dito num ouvido humano para que transdutivamente chegue à matéria. Mas também é dito diretamente a ela.

Como é nítido falamos aqui do acompanhamento de processos de criação e de ações pedagógicas, desde uma perspectiva não antropocêntrica, ${ }^{6} \mathrm{e}$ que procura pensar em ato a condição de que estamos no mesmo barco ${ }^{7}$ e onde queremos suspender os falsos problemas que reporiam a bifurcação da natureza como seria o par objeto/sujeito, ou ainda a humana demasiado humana pretensão de formação (colonização) de sujeitos que por sua vez subjugaria a agência e disposição ativa da matéria. Desde esta perspectiva que defendemos o humano é um meio mais entre outros para que proliferem aprendizagens mais do que humanas ou para que a aprendizagem das imagens possa acontecer. É assim como o curandeiro-educador, indiferente de que corpo o hospede, para poder fazer passar um (im)pulso criativo, tem que se dizer desmonte constante do sujeito, do ego, de qualquer interioridade que possa obstruir os fluxos da vida que pedem passagem; desmonte de qualquer vontade de assinatura e, portanto, de propriedade. Fazer dos corpos pura impropriedade de si, para que sejam propriedade da vida que por eles pede proliferar. Onde os modernos ainda veriam sujeitos a ser formados, nós só vemos conglomerados de afetos sem rosto ou nome, como componentes de uma ecologia mais complexa. Mãos que compõem, que articulam relações, que conectam propensões, que fazem da matéria material. Esta radicalidade aqui

\footnotetext{
5 JAMES, Essays in radical empiricism.

${ }^{6}$ Cf., por exemplo, a proposta apresentada por Simon CEDER em seu livro Towards a posthuman theory of educational relationality, na qual expõe as relações educativas desde uma perspectiva mais do que humana como orientadas por ocasiões e atmosferas de impermanência, de singularidades-comorelacionalidade e de graus de proximidade, onde pode tomar lugar uma "edu-activity" e onde de modo incerto aparecem limiares de inteligibilidade.
}

7 DEBAISE, Nature as event. 
proposta, também poderia ser pensada como um ganhar intimidade exacerbado com as materialidades do mundo, onde, no corpo a corpo, percebemos que somos mais uma delas como superfície por onde a diferença pode se deslizar.

Dispor-se a processos de co-criação, onde é fundamental cultivar a possibilidade de avaliar sem julgar, se perguntado pelos graus de consistência que manteriam em pé ou não a composição em jogo, não como mero exercício de sobrevivência, mas de ativação constante de possíveis $e$, portanto, de futuridades abertas. Tal avaliação de um processo criativo que passaria por um corpo singular, pediria mais do que escutar a uma subjetividade, fazer escuta dos procedimentos que esta movimenta. Escutar a operação e sua eficácia (suas consequências), mais do que o operador que sempre é anonimato dentro de um conglomerado de afetos. Vertiginosa situação, na qual nos abismamos com o outro no acompanhar de um processo de criação, para mutuamente desaparecer e que o mundo possa aparecer. Sendo que desta vez queremos nos deter num estádio particular da vida, quando ela é pura potência, mais do que realização. Insistir em permanecer num estado embriológico da matéria cinematográfica para ganharmos intimidade com a gênese dos processos de criação. Suspender a vontade de atingir uma forma última ou ainda pior de culminar numa obra, para assim não violentarmos os tempos do existir e perseverar no processo genético e generativo a partir de uma proposição pedagógica que tempos chamado "cultivo da imagem-ovo". Uma disposição pragmática e experimental que nos instala de cheio na embriologia cinematográfica que aqui queremos discutir.

\section{Segunda aproximação}

Não basta com se perguntar: $O$ que pode um corpo? Como se esta fosse uma pergunta individual que só nos cabe a nós mesmos. Em todo caso é uma pergunta que sempre diz de um "nós", de um conglomerado de corpos e afetos, pois sempre se é em relação e a relação é anterior aos termos. Não basta com querer salvar a própria pele, quando o que é preciso inventar é a instauração de um tecido mais rico e heterogêneo. Fazer corpo com, distribuir a potência, que a potência como perseverança singular do ser, seja o bem comum. Talvez esta possa ser uma primeira definição de uma possível pedagogia radical.

Como afirmar a potência desde uma perspectiva singular? Aliando-se, ganhando intimidade com uma prática, no meu caso a de cineasta. No entanto, não me interessa que outros corpos de modo "passivo" se vejam afetados pelos derivados da posição-cineasta que eu possa ocupar. Abolir a posição do espectador e em todo caso se dispor, a quem sabe e a risco de não funcionar, a devir uma sorte de catalisador da ativação da potência criadora de outros corpos. Sendo menos um educador no sentido tradicional e mais series coaprendentes na passagem de gestos de curandeiria, parteiria e doulagem. Isto é, favorecer que outros corpos também possam ocupar a posição-cineasta, sendo que eles mesmos deverão instaurar o modo como esta posição ganhara consistência dando lugar por sua vez a cinemas singulares. Cinemas como a emanação do encontro único entre um corpo e uma técnica.

De algum modo este foi o intuito da oficina "Pensar é sempre pensar por outros meios: Laboratório de pensamento cinematográfico" que tenho ministrado no 
Brasil (Centro de Pesquisa e Formação do Sesc - SP) e na Colômbia (Cinemateca de Bogotá e Faculdade de Educação da Universidade de San Buenaventura) entre 2019 e 2020.8 Nessa oficina, a partir da noção de modos de experiência cinematográficos, uma serie de experimentações multi-sensoriais foram abertas em direção ao que tenho chamado de embriologia cinematográfica ou do cuidado de imagens potenciais.

Sem uma ideia a priori do que é e pode - cinema, dar passagem a uma escuta atenta, profunda e radical das próprias imagens e onde tonalidades impensadas do pensamento podem ser desdobradas. Em outras palavras, onde acontece uma abertura para uma aprendizagem diagramática, como aprendizagem das próprias imagens. Isto é, como processos imaginantes de individuação em ressonância com a ideia de Deligny de "imagear", que nada tem a ver com a ideia de imaginar e onde se somos audaciosos poderíamos arriscar a dizer que acontecem processos de subjetivação das próprias imagens; além da ativação de uma pedagogia radical dos processos de criação como curandeiria e fazer escuta de uma ética do cuidado. Todo um apelo às processualidades do pensamento onde o cinema como movimento real se diz sempre por outros meios, se desliza sempre por outras superfícies sensíveis e especulares. Finalmente se perguntar pela gênese, pelo fazer nascer e, portanto, pela potência de engravidar e gestar dos corpos, antes que pela contemplação das formas. Como cuidar de uma "imagem-ovo"? Pergunta que não cabe só aos cineastas, mas a todo mundo e por isso talvez a minha vontade de abrir um devir-cineasta em todo mundo. Já que somos imagens entre imagens, como nos lembra Bergson ${ }^{10}$ e se perguntar pela gênese de uma imagem é também se perguntar pela gênese do pensamento. Neste ponto a pergunta do filosofo por como combater uma imagem dogmática do pensamento é iminentemente uma pergunta cinematográfica, pois é a posiçãocineasta a que cuida do devir das imagens, posição esta que pode passar pelo humano, mas não só. Posição que deve ser entendida também como imagem. Uma pedagogia radical, onde em última instancia o que se procura é reativar uma aventura do pensamento.

Trata-se então de cuidar que a imagem sempre esteja por vir. Neste sentido o gesto pedagógico procuraria curar toda vontade de fixação de uma formaCinema como vontade de poder que cancelaria $o$ devir das imagens. Trata-se de tomar distância diante dos hilemorfismos imperantes e promover metaestabilidades, onde as potências cinematográficas não responderiam a uma imagem dogmática. Falamos então de práticas pedagógicas nas quais os corpos incorporariam hábitos de se experimentarem como co-criações imaginantes que diante do tempo das catástrofes insistiriam em co-habitar um tempo das metamorfoses. ${ }^{11}$ Tempo no qual a imagem sempre estaria em potência, conservando qualidades

\footnotetext{
${ }^{8}$ Sou grato a Gustavo Torrezan por ter me aberto as portas do SESC-SP, assim como a Jeisson Manuel Méndez Portilla e a Andrea Rodriguez quem fizeram possível a minha presença no Cinemateca de Bogotá. Também agradeço a Teresita Ospina Álvarez por, de modo tão generoso, ter me acolhido na Universidade de San Buenaventura.

9 DELIGNY, Fuvres; PELBART, Contra os limites da linguagem, a ética da imagem.

10 BERGSON, Materia y memoria.

11 SALDANHA, O fim do futuro: o tempo das metamorfoses - o que pode a filosofia?; COCCIA, Metamorfoses.
} 
embriológicas e o cinema teria a capacidade de sempre se pensar e de dizer por outros meios. Pois o que está em jogo, é co-habitar o cinematografo cósmico e tal co-habitação imanente aos metamorfismos do ponto de vista da criação, só poderia acontecer como insistência na experiência, como variabilidade e proliferação de modos de experiência cinematográficos. Isto é, que abraçam $\circ$ intervalo como constituinte e disparador dos metamorfismos.

A proposição pedagógica do "cultivo da imagem-ovo", tem por protocolo que qualquer corpo a possa cultivar. Isto é, suspende a figura do profissional, do especialista, que também poderia se chamar artista, como sua condição de existência. Insisto, um corpo qualquer, mas sempre praticante de uma ecologia de práticas, que bem poderia ser mais do que humano. Pois, finalmente, do que se trata é de uma ação coletiva e em ecologia que acontece no encontro de conglomerados de afetos, que claro podem estar distribuídos pelos mais diversos corpos.

Tacitamente esta pedagogia radical implica a aprendizagem de que "nunca fomos humanos", 12 para que justamente aprendizagem mais do que humanas e das próprias imagens possam acontecer. Em outras palavras falamos do desmonte do sujeito e de sua vontade de intencionalidade, de falar no lugar das imagens, de colocá-las a seu serviço. Quando do que se trata é de escutá-las para poder dar lugar a que sejamos forçados a pensar, a escutar por sua vez o ponto de vista da criação que não para de se manifestar nas materialidades. Tornar notável que compartilhamos o mesmo plano existencial que as imagens como processos abertos e inacabados; ao, por exemplo, experimentar, dobrar e desdobrar a "imagem-ovo", ao fazê-la durar pelos mais diversos modos de experiência cinematográficos. Modos que talvez poderiam ser entendidos como ocasiões nas quais se cuida que a imagem sempre esteja em potência $e$, portanto, por vir. De repente, desde esta perspectiva o cinema se diz por outros meios como multi-sensorialidade e multirelacionalidade expressiva que pode ser acolhida por todos os sentidos para além da áudio-visão. Um cinema que como processo de mutua inclusão ${ }^{13}$ faz entrar também os corpos em metamorfismos. Corpos atravessando e sendo passagem para modos de experiência cinematográficos que se dizem auditivos, olfativos, tácteis e do paladar.

Os corpos implicados, que nas oficinas se dispuseram a compor uma ecologia de práticas, tinham como (im)pulso operador convidar uma imagem, e fazer dela uma "imagem-ovo" na medida em que não se lhe impusesse um horizonte de sentido e causalidade, mas se lhe cuidasse ao mantê-la aberta a partir do gesto de lhe fazer uma pergunta problematizadora. Isto é, uma pergunta instauradora de um campo problemático que a "imagemovo" faria pulsar sem procurar resolução, mas pelo contrário promovendo complicações no dobrar e desdobrar da passagem pelos modos de experiência cinematográficos propostos. Um duplo movimento no qual se suspendia uma e outra vez a intencionalidade de querer fazer da imagem um propósito, enquanto ela na sua condição embriológica era engravidada de possíveis. Uma ecologia de modos de experiência cinematográficos fazendo dos corpos conglomerados de afetos graças a uma

\footnotetext{
12 HARAWAY; GANE, When we have never been human, what is to be done?

13 MASSUMI, O que os animais nos ensinam sobre política.
} 
disposição idiota no sentido que Stengers

e Deleuze elaboram a partir de Dostoiévski. ${ }^{14}$ Há algo mais importante, mais urgente do que uma verdade como vontade de poder de atingir uma forma estável - forma-Cinema -. Pretensa verdade do filme antecipada como probabilidade (por exemplo, num roteiro),,$^{15}$ quando do que se trata é de escutar o chamado a se deter, a relentar o processo e permanecer no embrião, no potencial como verdade do relativo que contra toda probabilidade, cuida dos possíveis. Avançar, modular-se entre um modo de experiência e outro por fazer justamente da imagem algo improvável, mas pleno de potência. Imagem-ovo em ato.

Cuidar da imagem potencial e da potência da imagem como quem cuida de ovos cinematográficos e onde aprendemos que a imagem está sempre por vir, pois antes de tudo é um ovo cósmico em si mesma. Devir então parteira e doula ${ }^{16}$ como dobras curandeiras da pedagogia aqui proposta, como aprendizagens mais do que humanas, nas quais não cabe se perguntar que rosto, que qualidades mensuráveis terá a imagem. Pelo contrário, deter-se e cuidar do tempo da gestação e do nascer, que em última instância foi $\circ$ mote das oficinas ministradas. Abster-se tanto de abortar a imagem, como de violentar seu tempo germinativo por meio de operações do tipo "cesariana programada". Acolher o fato de que o tempo the pertence às imagens. Tempo cosmogenético, tempo das metamorfoses, ou como dirá Danowski e Viveiros de Castro, 17 tempo das transformações e de um incessante devir-outro. Assim sendo, a ética implicada no gesto de cuidar ovos cinematográficos, nos instala de cheio num tempo mitopoético, como manifestação especulativa de um pragmatismo cinematográfico no qual se compartilha a mesma respirar e ar com as imagens; para que como nos lembra Suely Rolnik, ${ }^{18}$ (2018), no seu encontro com o pensamento guarani e aqui fazendo uma torção no pensamento, as imagens encontrem sua alma, assim como as palavras também $\circ$ fazem na composição do termo "ñe'e raity". ${ }^{19}$

Esta pedagogia radical, cujo avesso é uma ética do cuidado, nos faz sentir a

14 DEBAISE; STENGERS, The insistence of possibles.

15 Falamos aqui do uso tradicional do roteiro, que de fato na história do cinema em parte surgiu como promessa capaz de mensurar a probabilidade de um filme. No entanto, o problema não estaria em si na ideia de roteiro, pois como sabemos também é uma forma expressiva muito potente. Pensemos, por exemplo, no filme de 1982 de Jean-Luc Godard Scénario du film passion. A questão estaria muito mais na vontade de querer reduzir processos a determinações e promessas dentro de uma lógica de causaefeito, que justamente $\circ$ cinema do processo e experimental quebrariam. Cf. MACKENZIE; MARCHESSAULT, Process cinema.

16 Sobre a arte da doulagem ver o trabalho de May Xué OSPINA POSSE La disolución del rostro o el reactivar de la bruja.

17 DANOWSKI; VIVEIROS DE CASTRO, Ha mundo por vir?.

18 ROLNIK, Esferas da insurreição.

19 Em referência Rolnik dirá: "Para os guaranis, tais necessidades são óbvias, como nos faz ver sua própria língua. Eles chamam a garganta de ahy'o, mas também de ñe'e raity, que significa literalmente "ninho das palavras-alma". É porque eles sabem que embriões de palavras emergem da fecundação do ar do tempo em nossos corpos em sua condição de viventes e que, nesse caso, e só nele, as palavras têm alma, a alma dos mundos atuais ou em gérmen que nos habitam nesta nossa condição. Que as palavras tenham alma e a alma encontre suas palavras é tão fundamental para eles que consideram que a doença, seja ela orgânica ou mental, vem quando estas se separam - tanto que o termo ñe'e, que eles usam para designar "palavra", "linguagem", e o termo anga, que usam para designar "alma", significam ambos "palavra-alma". Eles sabem igualmente que há um tempo próprio para sua germinação e que, para que esta vingue, o ninho tem que ser cuidado" (ROLNIK, Esferas da insurreição, p. 27). 
iminência de que a imagem na sua fugacidade e fugitividade é condição constituinte do vivente e existente $e$, portanto, como temos dito é processo de individuação vital. Frágil processo no qual como co-aprendentes e conglomerados de afetos devemos incorporar hábitos de hospitalidade, generosidade, humildade, cooperação, atentividade, responsabilidade e responsividade. Pois nos instalando por fora da representação, na vida e na oficina ministrada, apostamos por um cinema em chave menor que não quer se dizer toma de poder e, portanto de instrumentalização da imagem. Sem horizonte de determinação a priori, sem representação que entristeça os encontros e faça do humano uma imagem privilegiada e não mais uma imagem entre outras; dizer-se proliferação de zonas de indeterminação onde possam ser escutados e catalisados os ritmos embriológicos das imagens por vir, e que não é mais do que a aprendizagem vital e rítmica das próprias imagens.

Em meio à vertigem desta ontologia relacional, apre(e)ndemos que só quando abraçamos o fato de sermos imagens entre imagens que compartilham e cohabitam o mesmo ar, é que uma causa comum pode ser instaurada. Causa, onde - problema é reformulado não mais como uma tensão entre o humano e o não-humana, mas entre imagens e nãoimagens. Entre devir e estagnar ou abolir.
Terceira aproximação ou dos ovos cinematográficos em ato

Figura 1 -Modos de experiência cinematográficos olfativos e do paladar

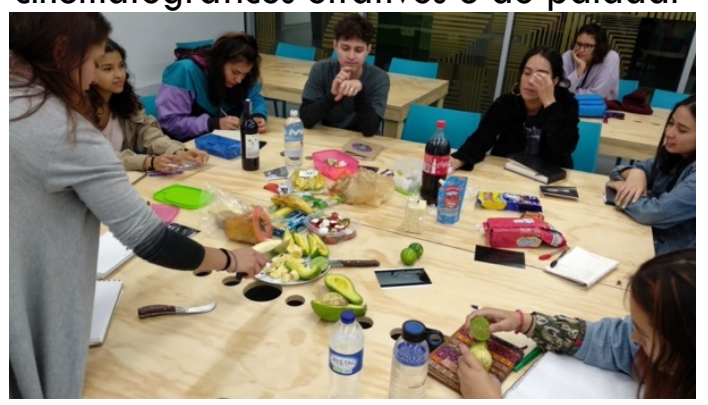

Fonte: acervo pessoal do autor.

Figura 2 - Modos de experiência cinematográficos tácteis

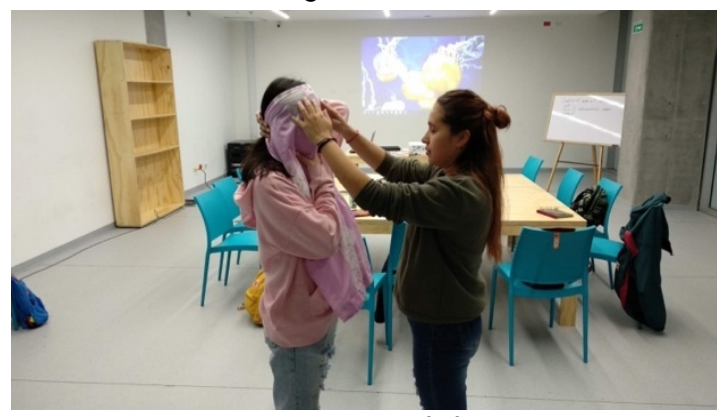

Fonte: acervo pessoal do autor.

Figura 3 e 4 - Modos de experiência cinematográficos auditivos na sua face
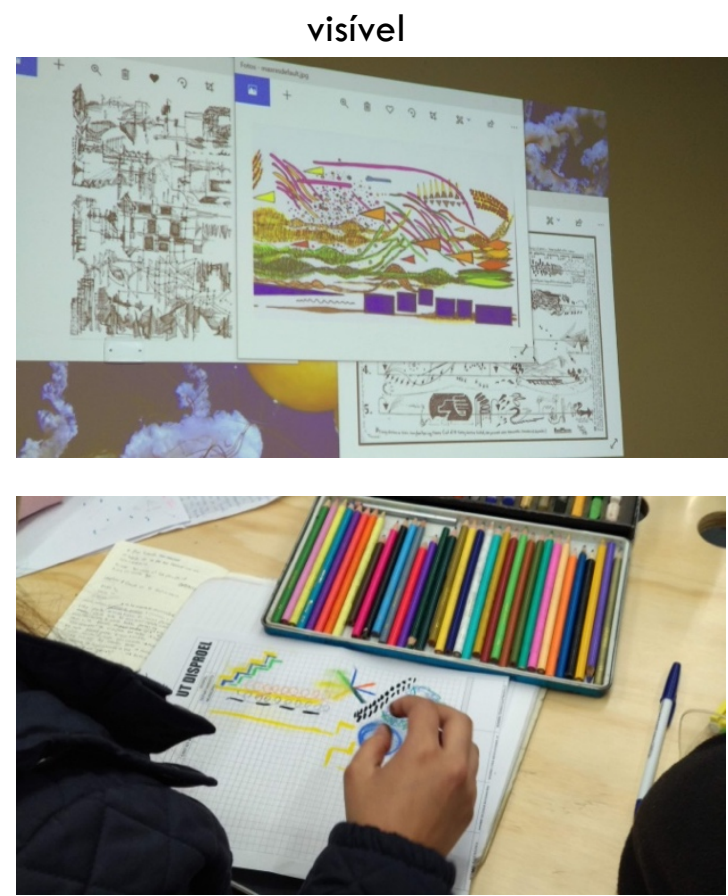

Fonte: acervo pessoal do autor. 
Figuras 5 - "Imagens-ovo" e seus devires em meio a modos de experiência cinematográficos auditivos feitos visíveis

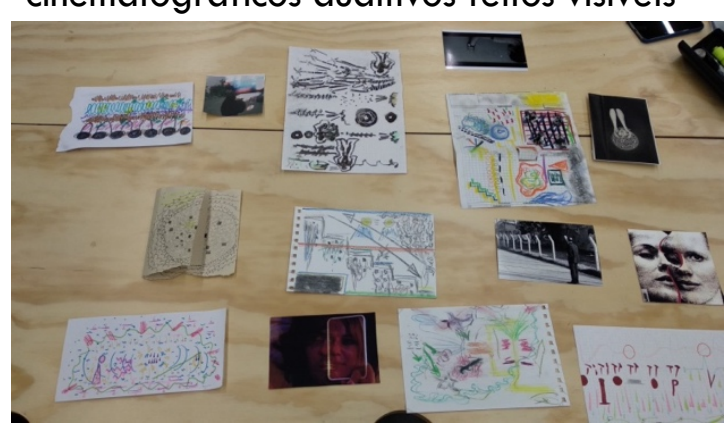

Fonte: acervo pessoal do autor.

Figura 6 - Encontro entre "imagens-ovo"

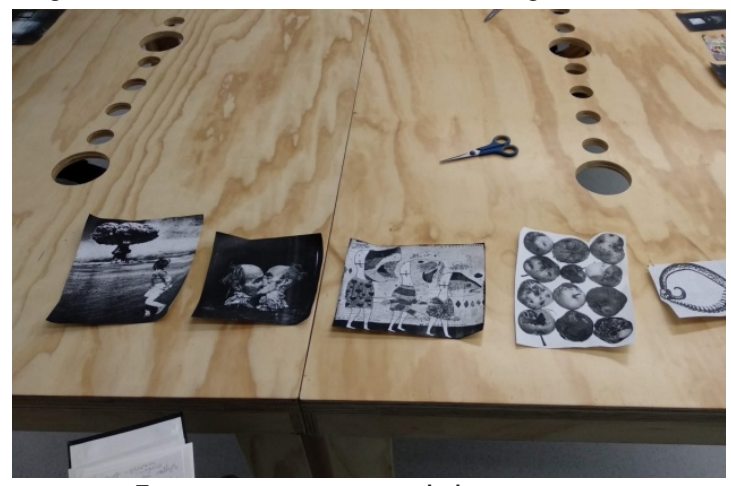

Fonte: acervo pessoal do autor.

Figuras 7 e 8 - Engravidar multi-escalar e dimensional de "imagens-ovo"
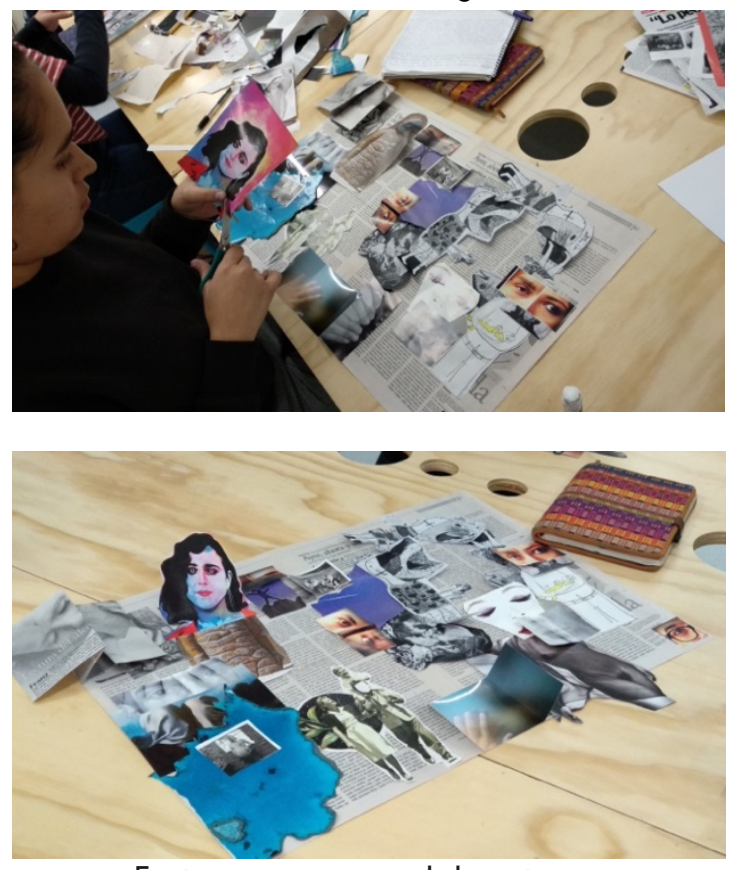

Fonte: acervo pessoal do autor.
Quarta aproximação ou da embriologia cinematográfica

Insistimos, não cair na tentação de dar continuidade formativa à imagem. Ralentar ao máximo todos os processos e permanecer no estado de embriologia cinematográfica para poder elaborar construtiva e potentemente um problema que oriente a individuação de modo consistente ao mesmo tempo em que aberto. Deter-se no embrião, no estado virtualizante $e$, portanto, diagramático da imagem. Mergulhar na sua profundidade intensiva que tende ao infinito e que ao mesmo tempo é desfundamento. $O$ embrião, como puro campo de individuação, de deslocamentos, migrações, dobras, torções, alongamentos... Toda uma plasticidade genética, como $\circ$ momento do impossível e dos movimentos aberrantes. Instalar-se justo entre 0 embrião e seu desenvolvimento, ali onde a diferença reina e sentimos a vertigem de que o mundo inteiro é um ovo, e o ovo é um teatro ${ }^{20}$ que temos que fazer durar, que temos que alongar para que 0 mundo não seja clausurado e a imagem como condição pluriversal possa continuar se dizendo corpo sem órgãos, ${ }^{21}$ como puro meio intensivo, como puro tempo das metamorfoses.

São de particular interesse os estádios interiores à embriologia que respondem ao nome de taquigênese e teratogênese. Por um lado, na taquigênese encaramos as instancias aceleradas da embriogênese, onde a complexidade é diretamente proporcional a seu coeficiente de velocidade. Quanto mais rápido, mais complexo, sendo que no meio das variações memorias genéticas são dobradas e desdobras. Neste sentido nos perguntamos e especulamos 
a favor dos possíveis, até que ponto a proposição pedagógica do "cultivo da imagem-ovo" como gesto criativo de uma biotecnologia sensorial, não é uma intervenção e, portanto, uma modificação na memória genética das imagens, como gesto involutivo, como possibilidade de implantação de memorias de futuro? Por outro lado, e sempre de modo incerto, tais implantações e intervenções na memória genética podem dar lugar a processos teratológicos, isto é, mutagênicos, onde as imagens podem devir pura anomalia e monstruosidade criadora.

Nesse ponto, poderíamos dizer que aquilo que anteriormente chamamos de kino-madologia nas suas dobras contem não só dramatologias de um teatro sem sujeitos ou de forças larvais atuantes, mas também oologias e cosmologias ${ }^{22}$ que não param de se precipitar num cinema da imanência, que longe de interpretar ou representar $\circ$ real, se diz produção eficiente da diferença.

Instalando-nos em meio a uma embriologia cinematográfica, assim como por meio da proposição pedagógica do "cultivo da imagem-ovo", privilegiamos um pensamento da gestação e germinação de ideias cinematográficas no limite do vivível e do vivente que povoa as próprias imagens como dobras larvais que dão expressão a um campo de individuação como teatro de todas as metamorfoses dramatizadas pelas intensidades que não param de pipocar e onde é impossível adivinhar os devires, pois a vida-imagem se diz improvisação composicional. Será do comportamento e de sua disposição relacional na passagem pelos modos de experiência cinematográficos que aquilo de Ruyer define como sobrevoo do ser, persevere e se intensifique ainda mais. ${ }^{23} \mathrm{Em}$ outras palavras o jogo pedagógico que aqui é encenado promove que nas imagensembriões seja ativado um processo de autopossessão ou se se quer de potência em ato que se automodifica e altera as trajetórias. A imagem encontra problemas e improvisa soluções com os elementos a sua disposição (sejam estes mãos humanas ou outras imagens).

Cada modo de experiência cinematográfico problematizando a imagem-embrião, forçando torções e dobras impendas nela que a fazem funcionar como um pequeno deus autocriador e imanente (assim como imaginante), que é mãe, pai e filho de si como diria Artaud. Quer dizer, que o que é promovido nestes exercícios é um desapego das próprias imagens por terem uma identidade que as possa fixar, pois dependendo da situação em que estejam em jogo estarão dispostas a comprometer todo seu potencial na metamorfose que a situação exija. Neste sentido só nos cabe escutar e favorecer as propensões que emergem do encontro entre as imagens $e$ as situações que fazem do processo embriológico e morfogenético o modo pelo qual a vida não é só resistência diante da morte, mas também criação ${ }^{24}$ que no cinematógrafo cósmico não para de pulsar nos intervalos.

A imagem-embrião não serve, não é servidão, pois é puro desenvolvimento sem horizonte, puro funcionamento para além de uma forma, ou ainda pura plasticidade milagrosa como dirá Ruyer e que será $\circ$ que tanto interesse a Deleuze. Isto é, fazer da vida uma performance criadora. Esta seria 
também a razão pela qual apelaríamos a uma embriologia cinematográfica como a metamorfose que $\circ$ Azul profundo tem vivido ao friccionar seus limites. Ativar e abrir a dimensão performática da imagem como potência criadora, pois:

a qualidade embrionária sinala no mundo a presença ou subsistência de uma potencialidade imanente, uma vida que se atualiza, se diferença e improvisa. A postulação desta vida embrionária do mundo possibilitaria pensar, para além das formas constituídas, mas sem por isso negando-as, a possibilidade inerente de transformações impensáveis. ${ }^{25}$

A embriologia cinematografia permitiria nos determos no tempo das metamorfoses para que a imagem-ovo possa explorar seus limites transformacionais sem qualquer tipo de vontade transcendente (ou do sujeito que a determine), mas sim e aqui incorporando um pampsiquismo como o de Ruyer, carregando uma "memoria orgânica" que diz de uma interdependência transindividual ${ }^{26}$ e que daria lugar a uma continuidade entre todos os viventes que faz com que eles lembrem que tem que afirmar pelos mais diversos meios o ponto de vista da criação. A vida que migra entre as imagens e que no estado embrionário delas se diz automigração de si, pois há algo que na imagem-embrião é pura força de re-aparição na sua constante re(des)composição, a saber a diferença. Desta maneira a embriologia cinematografia em meio a seus dinamismos incessantes nos permitiria explorar essas linhas de continuidade pelas quais a diferença desponta como disparação vital sem abrir mão das singularidades. Algo como um retorno aos elementos mais concretos da existência, mas também mais dinâmicos, ${ }^{27}$ onde nos re-conectaríamos com essa "memoria orgânica" e imaterial responsável pela concatenação processual dos elementos materiais necessários à co-composição e co-criação das imagens como campos de individuação. Tal "memoria orgânica" é potência e vibração rítmica que pulsa nos intervalos não como elemento primeiro da vida, mas como princípio de conectividade que a faz proliferar como relação. "Memoria orgânica" como condição de atualização do potencial, como o cerne das aprendizagens mais do que humanas e, portanto, como aquilo com $\circ$ que os conglomerados de afetos da ecologia de práticas aqui em jogo procuram se re-ligar através de proposições pedagógicas como a do "cultivo da imagem-ovo".

Não há imagem, nem vida sem memória como nos lembram Ruyer e Bergson, ${ }^{28}$ pois a "memoria orgânica" em última instancia é o que permite a reunião de elementos e a ativação dos processos genéticos na matéria como conectividade disponível em circuitos mais amplos da própria memoria ${ }^{29}$ e de seus gradientes imaginantes. Isto é, a pedagogia radical que aqui se coloca de manifesto apostaria na desaceleração da percepção para que a partir de um diferencial de velocidade possamos nos desviar de uma memória humana demasiado humana em direção à possibilidade de relembrar ou de nos religarmos com uma "memoria orgânica" e, portanto cósmica como velocidade irrestrita do ponto de vista da criação feito cintilações do cinematografo

\footnotetext{
25 PACHILLA, El mundo entero es un huevo, p. 51.

26 SANTOS, Habitando mundos.

27 SANTOS, Habitando mundos.

28 BERGSON, Materia y memoria.

29 SANTOS, Habitando mundos.
} 
cósmico. Aprendizagens mais do que humanas, como incorporação de memorias que nos fundem com a vida e o estado embrionário dela expresso nas imagens, reconhecendo que onde há memoria, não só também há vida, mas, sobretudo, inteligência (como capacidade agenciativa) ou nos termos de William James, ${ }^{30}$ consciência. Dali que nos caiba aprender a escutar a inteligência intervalar que as imagens carregam no seu maior grau de potência quando se dizem ovos como consciênciamundo em ato e criação. Toda uma kinomadologia como curandeiria do tempo, onde aprendemos que a arte de cohabitar um mesmo plano existencial e temporal e, portanto, acontecimental com as imagens, é aprender a co-habitar memorias que podem ser desdobradas e intensificadas por meio de modos de experiência cinematográficos, onde podemos lembrar, por exemplo, como nos diz Ruyer que:

A forma do nosso organismo também inclui, aparentemente, a conjuntura históricogeográfica geral, isto $e$, as condições cosmológicas de vida sobre este planeta: a memória orgânica prepara os pulmões, o que está em consonância com a existência do oxigênio no ar terrestre; ela constrói olhos, que possui um sentido dado à existência da luz solar [...] Dizemos então que se gostaríamos que ela se lembre - este e o papel da memória orgânica - não apenas de fabricar o pulmão e os olhos, mas que existe o ar e a luz para utilizar. ${ }^{31}$

Devir cuidador de ovos cinematográficos, algo tão simples e tão complexo; esse foi - intuito das oficinas ministradas onde também a pedagogia radical dos processos de criação procurou fazer do "eu" esquecimento, como condição constituinte para se instalar no tempo das metamorfoses, onde em sintonia com o fazer das parteiras e doulas, se fez perceptível que dar a luz, não é mais do que dar lugar à migração da vida na qual devimos entre-imagens como quimeras existenciais que vehiculizam possíveis. ${ }^{32}$ Do mesmo modo, se fez nítido que assim como $\circ$ nascimento, $\circ$ estado embriológico das imagens não é um estádio limitado ou circunscrito, mas que pode e deve estar em expansão e proliferação. As imagens como a vida nunca abandonam por interior este estado de máxima criatividade. Em outras palavras, fazer com que a imagem-ovo, não seja apenas um início, mas que sua condição oológica retorne sempre por outros meios; que não seja algo só pré-natal, mas também pós-natal ou ainda trans-natal. Ali, como nos lembra Coccia, ${ }^{33}$ a imagem-ovo que se diz imagem-metamorfose seria apenas a transposição do "mecanismo morfogenético do embrião na vida pósembrionária".

Trata-se então de fazer das imagens embriões livres e sem casca. Ovos ambulantes como potência movente. Aprender a escutar os seus ritmos para que elas, as imagens; por sua vez engendrem mais ovos, fazendo de seus metamorfismos uma embriogênese continuada. Sentir no corpo que é impossível abandonar um estado de gestação, pois sempre se está devindo embrião como gesto de permanecer num estado de infância da vida. A "imagemovo" que também faz de "nós", do "eu" e de tudo um ovo. Gestação redobrada sobre si, ou para melhor dizer o vivente como pura força de gestação, onde aprendemos que se antes era necessário conjugar o verbo azular, para abrir o verbo humanar a conjugações impensadas, agora é indispensável

\footnotetext{
30 JAMES, Essays in radical empiricism.

31 RUYER, Elements de psycho-biologie, p. 66.

32 COCCIA, Metamorfoses.

33 COCCIA, Metamorfoses.
} 
aprender a conjugar 0 verbo chocar para incorporar a aprendizagem de que - ressurgir de ovos é a pura potência do "entre" que faz proliferar a vida nos intervalos.

A proposição do "cultivo da imagemovo" ensinando-nos a reinventar a nossa relação com o tempo, uma vez que o ovo nos doa um puro tempo intenso, como contração de tempos que abrem futuros e infâncias em nós e nas próprias imagens. Como efeito, poderíamos pensar as ações pedagógicas postas em jogo como a pergunta pela ativação da infância das imagens, onde a infância é entendida como uma questão de relação, de máxima relacionalidade num máximo de direções. Dali que poderíamos arriscar a pensar que toda ecologia de práticas, incluindo a que aqui encenamos, é uma teoria dos ovos por outros meios, ${ }^{34}$ pois toda relação ecológica é uma relação metamórfica. E se o mundo é um ovo, a proliferação de conglomerados de afetos aqui mobilizados, como entreimagens, são metamorfose de mundo. A imagem, como dobra-mundo, contendo outros mundos, sendo aparição de um pluriverso em expansão, onde nós como cuidadores a instigamos a que como infância brinque com seus limiares existenciais entre invaginações e gastrulações.

Neste ponto também é interessante perceber como a embriologia cinematográfica nos ajuda a pensar a técnica desde uma perspectiva não antropocêntrica. Como disposição pedagógica, ela já é uma técnica (de escuta) para que as imagens encontrem as suas próprias técnicas (como devir delas mesmas), entendendo a técnica não como $\circ$ prolongamento do humano que faria do mundo uma extensão dele e que tem nos levado ao Antropoceno, como tempo das catástrofes; mas onde é entendida como o que articula e conecta e, portanto torna possíveis as relações. Nesse sentido a técnica já é em si infância e ovo, ${ }^{35}$ pois é propensão em direção a um máximo de relacionalidade num máximo de direções que constantemente esta desfazendo e desmanchando a "nossa" imagem (como modelo), suspendendo assim a vontade projetiva que antrópizaria o mundo. Imagem-ovotécnica cuidando dos dinamismos $e$, portanto, do tempo das metamorfoses, ao não parar de funcionar como um diagrama.

\section{Quinta aproximação ou do diagrama}

\begin{abstract}
E se pensarmos que as imagens estão mais próximas a uma membrana, que separa e também conjura, um interior sempre mais profundo, da ordem da memória, e um exterior cada vez mais longínquo, da ordem da lembrança e do esquecimento. A imagem agiria, desse modo, muito mais próxima a um diagrama, relacionado ao local de proximidade máxima da experiência, configurando um certo tipo de mapa voltado para a experimentação ancorada no real. ${ }^{36}$
\end{abstract}

A imagem como diagrama e como pensamento diagramático, onde tornaríamos afirmativa a nossa relação com a catástrofe. Pois como nos lembra Deleuze, ${ }^{37} \circ$ diagrama diz do embate que se trava com a catástrofe e o caos, no qual se pode sucumbir, mas do qual se procura extrair uma novidade. É no diagrama que acontece a passagem de um tempo das catástrofes para um tempo catastrófico, como tempo das metamorfoses e onde se cultiva uma

\footnotetext{
${ }^{34} \mathrm{COCCIA}$, Metamorfoses.

35 COCCIA, Metamorfoses.

${ }^{36}$ AMORIM, Diagramas para um currículo-vida, p. 418.

37 DELEUZE, Francis Bacon.
} 
disposição para o acontecimento a partir de uma escuta de potências ainda não realizadas, de virtualidades ainda não atualização. Neste sentido o diagrama sempre escapa à representação e é o lugar da insistência dos possíveis. ${ }^{38}$

A proposição pedagógica que insistimos em ruminar aqui procuraria então que ganhássemos intimidade com um tempo catastrófico onde escutaríamos as imagens para além do que elas têm a oferecer como visualidades. Escutaríamos muito mais o que elas podem como campos de individuação. Isto é, entrar em relação com elas como diagramas e a partir de uma escuta diagramática. Pois elas não são, mas passam e nosso apelo seria muito menos por seus modos de parecer, por suas formas, e muito mais pelos ventos que entre elas passam. Esse murmurinho de futuridade que $\mathrm{faz}$ do cinema uma técnica expandida de pensamento e da aprendizagem, entre elas e nós, entre um "nós" como entreimagens e $\circ$ mundo, algo coletivo e impessoal. Aprendizagem mais do que humana.

O diagrama também diz da germinação, e pode ser pensado como um caosgerme, ${ }^{39}$ como um disparador de situações de "pode ser, poderia ser, mas ainda não". Campo fértil para os possíveis. Sendo assim, poderíamos dizer que onde a representação vê um contorno definido, nós vemos um berçário fervilhante de possibilidades, pois toda imagem é uma fractalidade de outras imagens e de imagens-outras. Aprender então a ativar uma percepção visionaria, alucinada e delirante, onde uma imagem é sempre a potência de um mundo por vir. A imagem arrasta um pluriverso inteiro em cada uma de suas dobras. No entanto não está dado que seja um diagrama, ele tem que ser inventado localmente uma e outra vez e a cada vez. Algo que a risco de não funcionar, pode vingar na experimentação de modos de experiência cinematográficos. $\mathrm{E}$ onde tal invenção poderia ser estimulada a partir de proposições de uma pedagogia radical que funcionem como protomarcas diagramáticas, no sentido de marcas destituintes de graus de representação que insistem em querer ressurgir. A aposta no "cultivo da imagem-ovo".

O diagrama funciona então como um limite dinâmico, como um umbral ou até mesmo como um "fio de metamorfose". 40 Mas também funciona como uma borda de emergência que no limite da existência faz existir. ${ }^{41}$ Neste sentido, o diagrama, como puro limite de borda feito terceira margem, ${ }^{42}$ não deixa de ser também "uma técnica construtivista de existência, de trazer uma nova existência; uma técnica de devires". ${ }^{43}$ Nós diremos uma técnica de re(des)composição, que também é fronteira aberta e ilocalizável para as migrações da vida. Dobra que do potencial faz existência ao filtrar e traçar novas construções para que novas co-habitabilidades possam emergir. Sendo assim, no limite, instalar-se no pensamento desde uma perspectiva processual, é fazer dele um diagrama. Então, fazer da imagem um diagrama, para com ela diagramar caminhos impensados para $\circ$ ponto de vista da criação, onde não para de acontecer um

38 DEBAISE; STENGERS, The insistence of possibles.

39 DELEUZE, Francis Bacon.

40 ORLANDI, Arrastões na imanência.

41 MASSUMI, Semblance and event.

42 Pensamos aqui no conto de GUIMARÃES ROSA, A terceira margem do rio.

43 MASSUMI, Semblance and event, p. 100. 
processo de re(des)composição de modos de habitar a experiência. A variabilidade ilimitada dos modos de experiência cinematográficos.

Imagem-ovo como imagem-diagrama se autoengendrando. Então a par de nós, como entre-imagens, uma realidade também é engendrada sem passar pela representação e se dizendo real por vir como potência conectiva. Em outras palavras, as imagens-ovo-diagrama nos ensinando que nelas já há montagem. Pois a montagem como a relação, é primeira. Isto é, escutar as imagens como aprendizagem mais do que humana é também escutar a teoria da montagem que nelas já está implicada e que é potência perspectivistica e intervalar de mundos. Uma escuta diagramática, aquilo que uma pedagogia radical não para de cultivar ao orientar a percepção em direção ao futuro. Uma escuta das sugestões já presentes nas materialidades, como exercício de ganhar intimidade com uma concretude abstrata ao mesmo tempo em que com uma abstração concreta, onde sensação e ponto de vista ganham duração; $e$, portanto, conseguem se dizer princípio de redistribuição das relações, das montagens e em consequência dos intervalos em jogo.

Estas relações já estariam presentes virtualmente no diagrama, pois ele é o lugar para pensar 0 dinamismo entre $\circ$ virtual e o atual. Assim sendo, ele é um campo de livre experimentação entre forças que não para de sugerir realidades por vir. Dali que possa se dizer que "o diagrama age como modulador" de zonas de transição, ${ }^{44}$ onde ele se afirma como "uma espécie de máquina que cria perspectivas (mundos possíveis)" 45 ao se instalar no "entre". Guattari ainda dirá que o diagrama é aquilo que está "por trás" escapando às coordenadas da existência por ser ilocalizável por mais que esteja ao mesmo tempo "na mente" e nas coisas. ${ }^{46}$ Isto é, no "entre" especulativo que engendra possíveis. Mesmo "entre" que não temos parado de explorar e experimentar ao mergulhar no Azul profundo, ou ao mergulhar na proposição pedagógica do "cultivo da imagem-ovo".

O diagrama como a moradia do desigual e de todos os ritmos antes de serem ○ ritmado. Dimensão instável, agitada e de misturas, onde as forças estão num perpetuo devir e que age como causa imanente não unificadora. É dizer, como campo ilimitado de possibilidades que produz perspectivas, que se instalam antes do narrável, da história por serem fiéis ao tempo do acontecimento. Dali que as práticas pedagógicas sejam chamadas a se dizer espaços de re(des)composição, onde pontos e marcas de emergência e criatividade sejam espalhadas aqui e acola, como ocasiões de confrontação dos corpos e materialidades com seus limites, que com sorte, os forçarão a que se modifiquem junto com a ocasião; pois - diagrama não para de desestabilizar ordens já dadas na sua procura por fugir dos clichés como a forma morta, que o obriga a abrir zonas de indeterminação e indiscernibilidade, onde já não se é mais e ao mesmo tempo ainda não se é. Algo profundamente assustador $e$ vertiginoso, pois se trata de estar submerso no diagrama e na imagem feita textura imaginal, onde $\circ$ fora cutuca selvagemente jorrando vetores

\footnotetext{
44 ROQUE, Sobre a noção de diagrama, p. 96.

45 SALDANHA, O fim do futuro, p. 299

46 SALDANHA, O fim do futuro.
} 
modificadores da realidade. Todo um processo involuntário, onde as marcas de emergência e criatividade podem, quem sabe, abrir alguma tendência. Toda uma pedagogia promovendo a ocupação por parte dos corpos implicados de uma posição insólita entre o caótico e o atual. Há risco de desmoronamento, mas sem risco não há nem pensamento, nem continuação da vida. E nos tempos catastróficos que vivemos há de se reevaluar as ideias que se tem de prudência, pois na beira de uma avassaladora extinção da vida e de seus processos criativos, a maior prudência é redobrar a aposta e se abismar no tempo das metamorfoses por mais perigoso que possa parecer. É por isso que o diagrama é constantemente posto a prova, pois ele só se manifesta para introduzir possibilidades de fato, para que algo surja como condição de que o futuro não seja cancelado. Se algo não surge, ele fracassa. Mas quando tem sucesso, se diz corte que instaura (a possibilidade de) um mundo, que nos devolve em troca "um efeito psicotrópico por expandir e transformar os limites experimentados da realidade". ${ }^{47}$

Aprendizagens mais do que humanas, nas que, como transições, escutamos a propensão da vida, da matéria, enquanto se faz material. No meio se passou pelo diagrama e o novo não foi perdido de vista. No meio a imagem-ovo se fez efeito psicotrópico, pois os conglomerados de afetos em expansão e proliferação conseguiram experimentar a realidade de outra maneira. Ou seja, - "mais-que" intensivo da percepção ${ }^{48}$ que é o diagrama, como a antecipação imperceptível do por vir, agindo como corte e interferência no já dado e tornando notável que "a matéria já está engravidada de capacidades morfogenéticas, sendo capaz de produzir por si mesma transformações". 49 É assim, como o diagrama se diz motor de re(des)composições, onde o problemático deixa de ser pensado em termos de sujeito ou objeto, e em troca é pensando em termos de acontecimento. Esta seria sem dúvida uma das qualidades do que entendemos aqui por uma pedagogia radical dos processos de criação. Pensar processos orientados pelo chamado a co-habitar o tempo das metamorfoses, dos acontecimentos, dos por vires. Perguntar-se pelo que emerge e que sempre acontece no entre de materialidades acentradas. Apostar por práticas diagramáticas, como instancias de circulação e modulação 50 e onde a realidade é sempre a frágil e instável disposição de nodos afetivos postos incessantemente em variação pelos cortes que justamente $\circ$ diagrama exerce.

Imersos e co-habitando uma comunidade de conglomerados de afetos cada vez mais rica, aprendemos e nos dispomos a que a percepção aconteça no nível da matéria e não do humano, pois nos entendemos como co-emergências relacionais de materialidades sensíveis que não param de se engravidar de potências que nos exigem que 0 diagrama como técnica de existência seja uma prática constante. Ali a imagem-ovo e as práticas pedagógicas experimentadas nas oficinas nos ensinam que a imagem é um "mais-que". Logo então, devemos aprender a prestar atenção a esse "mais-que" e que faz com que não saibamos mais onde a imagem começa ou termina, e, portanto, que

\footnotetext{
47 SALDANHA, O fim do futuro, p. 312.

48 MANNING, Always more than one.

49 DE LANDA, Deleuze, diagrams, and the genesis of form, p. 34.

50 MANNING, Always more than one.
} 
também deixemos de saber onde nós e o mundo começam ou terminam. Nesse ponto podemos dizer que a pedagogia radical experimentada nos modos de experiência cinematográficos não só abre uma disposição e percepção idiota, mas também autista. ${ }^{51}$

\section{Sexta aproximação ou de uma pedagogia radical:}

Figura 9 - "Não Há Cartografia no Mundo dos Pajés. Reescritura sob Perspect-ativismo" (2020) do artista indígena Denilson Baniwa

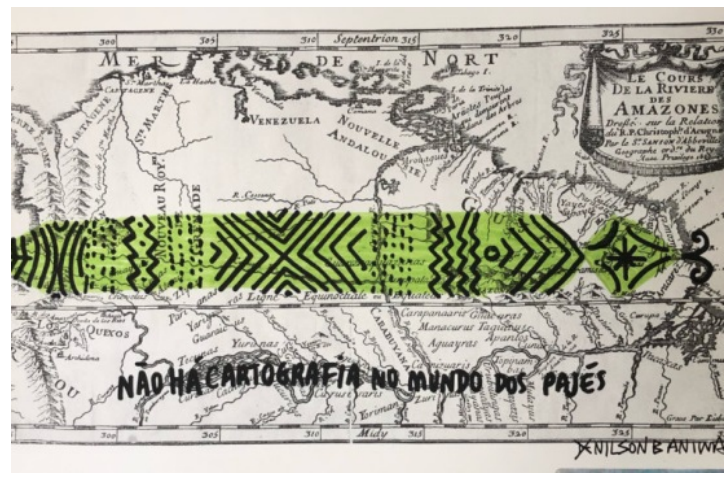

Fonte: Imagem cedida pelo artista.

Uma pedagogia radical orientada ao acontecimento sempre tomara partido pelo diagrama antes que pela cartografia, pois, parafraseando o título da obra de Denilson Baniwa e entendendo aos pajés também como agentes de curandeiria: No Mundo dos Pajés $\circ$ que há é pensamento diagramático!

$*$

Insistimos então em pensar com a figura da curandeira, pois como a bruxa é profundamente pragmática, ${ }^{52}$ explicitando não só uma intimidade com - cuidado, mas também com alianças mais do que humanas, sejam estas vegetais, elementares, telúricas, azulantes... A curandeira, que muitas vezes se diz também parteira, sabe muito bem que a vida sempre cresce para baixo se enfiando fundo na terra, ${ }^{53}$ ou como temos experimentado, no profundo do Azul. A transmutação do tempo das catástrofes no tempo das metamorfoses parece-nos que exige um contágio, uma hibridação entre a curandeira e o educador, para efetivamente poder instaurar um campo profícuo de conglomerados de afetos como disposições co-aprendentes. Uma aliança demoníaca, como diriam Deleuze e Guattari, 54 capaz de intensificar uma hospitalidade e uma ética do cuidado necessárias às aprendizagens mais do que humanas que pede o clima do tempo que vivemos, para que em meio a um mundo devastado e em ruínas, 55 possamos insistir em permanecer no instante da eclosão, do desabrochar. Um clima do tempo, onde em meio a furacões e pestes, mais do que nunca é necessário permanecer com o problema de uma polinização transversal do pensamento. Não só a curandeira que poliniza o educador, mas o Azul profundo que se faz pura polinização, por exemplo, ao fazer do seu azular uma tonalidade multicolor no "cuidado da imagem-ovo". Fazer com que as ecologias de práticas que aqui defendemos sejam "ecologias de emissões e disseminações" 56 onde 0 curandeiro-educador se diz também intercessor-polinizador.

\footnotetext{
51 MANNING, The minor gesture.

52 STENGERS, Reativar o animismo.

53 OSPINA POSSE, La disolución del rostro o el reactivar de la bruja.

54 DELEUZE; GUATTARI, Mil mesetas.

55 TSING et al., Arts of living on a damaged planet.

56 PELBART, $O$ avesso do niilismo.
} 
Uma arte dos bons encontros, onde mais do que fazer escutar algo que pudesse estar silenciado (um fazer-se escutar de um outro), se abrem condições para um "fazer escuta", onde a escuta se faz acontecimento em meio as mudanças da ocasião em jogo. Antes do que "um fazer-se escutar" que emitiria palavras de ordem ${ }^{57}$ e, portanto, reporia atos de representar ou interpretar, falamos de "fazer escuta" como o acolhimento de outrem, que só emerge na criação de vínculos, de conexões impensadas. Isto é, - "fazer escuta" não pressupõe técnicas (de fazer escutar), mas as inventa no encontro.

Do mesmo modo, diremos que a cada vez o espaço pedagógico deve se reinventar não como lugar de escuta, mas como "lugar da escuta". ${ }^{58}$ Um lugar de estranhamentos, não como o lugar da posição de um sujeito, mas como o lugar em que a escuta tem lugar enquanto a condição de todo lugar de escuta. Desta maneira, assim como a relação é anterior aos termos, o "lugar da escuta" também o é ao "lugar de escuta". Isto é, o "lugar da escuta" demanda que sempre ocupemos um lugar (estrangeiro) de escuta. Em outras palavras onde a audição se faz sempre oblíqua, e, portanto, se diz prática de equivocação, 59 mas também de deformação, devoração e especulação.

*

No acúmulo das ruminações feitas até aqui, poderíamos dizer que uma pedagogia radical procuraria promover - hábito de nunca perder de vista experiência, de nunca sair de um corpo a corpo com a matéria, e, portanto de levar ao limite as experimentações em jogo sem o perigo que podem provocar os a priori, as pressuposições e as relações externas e abstratas. Tudo isto, como temos sublinhado exige um compartilhamento de risco por parte dos implicados e que habilita um fazer escuta dos procedimentos que estão sendo mobilizados na prática. Ali a aprendizagem sempre mais do que humana se diz meio e processo sempre inacabado de apreensão de forças que potencializam a emergência do novo e a proliferação da vida nos seus metamorfismos. Assim sendo o curandeiro-educador é um ativador, um mobilizador de sensações e forças criativas que dão lugar a consonâncias diagonais, a transversais plurais onde se insinua e delira juntos; sendo tudo sempre fugas e tangente, e onde ensinar é reaprender ou para melhor dizer coaprender com o outro do outro.

Nessa co-aprendizagem onde devimos conglomerados de afetos impessoais, como canais e posições variáveis somos também atractores de relação e afetação, puros "lure for feeling". 60 E como é mais do que nítido nunca se diz do processo, como quem está fora do barco, mas se é processo a mar aberto e nas águas mais turbulentas. Nunca se diz "de" ou "sobre" algo, grande perigo de cair nas palavras de ordem (quando toda palavra deveria ser de passagem), mas no meio das agitações afetivas se é ressonância não intencional onde nunca se sabe muito bem quando as aprendizagens começaram ou irão terminar. Elas finalmente nos passam, passam por nós e seguem. Ali mais do que nunca $o$ corpo é pensamento $e$,

\footnotetext{
57 FERRAZ, Livro das sonoridades.

58 NODARI, Lugar da escuta.

59 VIVEIROS DE CASTRO, Metafísicas canibais.

60 WHITEHEAD, Process and reality.
} 
portanto, nunca pode ser deixado de fora $e$ as aprendizagens se afirmam como o caminho de se tornar digno do movimento, enquanto este acontece e nos jogamos nele. Em consequência, e aqui pensando para além da instituição, a educação não poderia ser mais do que um cenário metamórfico de possibilidades e experimentações (como de fato tem sido o Azul profundo), onde as aprendizagens são atos de criação, de invenção de relações não dadas e onde como nos lembra Deleuze ${ }^{61}$ nunca se aprende fazendo como alguém, mas fazendo com alguém num fazer que sempre se diz diferentemente. Educação, então, como a emergência sempre frágil e efêmera de comunidades de coaprendentes em disposição de "fazer escuta" e de se tornar "lugar da escuta" dos ritmos embriológicos da vida e do mundo. Educação como propensão de re(des)composições mais do que humanas.

Ainda pensando com Luiz B. L. Orlandi, 62 a pedagogia radical que aqui nos convoca poderia ser pensada como uma pedagogia dos diferencialismos, do repetir diferentemente em aliança com uma ética do cuidado profundamente spinozista, onde a multiplicidade e complexidade seriam constituintes às aprendizagens que nos forçam a pensar. Uma pedagogia como invenção das condições do intensivo para justamente permanecer na matéria intensa, onde a cada lance de aprendizagem só haveria ovos e larvas implicados em circuitos de intensidades entre energias. Desencadeamentos diferenciais aqui e acola, devires que nada tem a ver com uma vontade de estocar conhecimento, mas onde pelo contrário se procura salvaguardar a experiência devindo um elo para a diferença, que farejador avança por de-formações. No meio, e cultivando a arte de prestar atenção, só nos caberia como curandeiroseducadores sugerir vieses para as aprendizagens (sempre mais do que humanas). Esta pedagogia não pararia de se perguntar pelo desejo, entendido como processo de produção sem referência a qualquer instância exterior. Em outras palavras, uma pedagogia como campo de imanência do desejo que não responderia ao poder, mas sim à potência, sempre cuidando que os ovos cinematográficos não virem ovos da serpente. A cada gesto de coaprendizagem, fazer-se a pergunta pragmática: como este gesto está contribuindo ou não para atingir o máximo de potência que pode o corpo que habito em relação a seus poderes de afetar e ser afetado, e que consequências tal contribuição teria afetivamente dentro da ecologia na qual estou inserido como entre-viver em cocriação?

Melhor dizendo, as proposições desta pedagogia radical, passando pelo Azul profundo em si mesmo e seus desdobramentos como o "cultivo da imagem-ovo" almejariam a que a expressão atingisse a sua condição mais potente, mais intensa em um pensamento sempre encorpado e corporificado. ${ }^{63}$ Isto é, honrar coletiva, mas também impessoalmente a autonomia da expressão a partir de técnicas especulativo-pragmáticas muito

\footnotetext{
61 DELEUZE, Proust e os signos.

62 ORLANDI, A respeito de ensinar e aprender.

63 MASSUMI, The principle of unrest.
} 
precisas $^{64}$ como a que temos exposto, dobrado e desdobrado aqui, e que sempre na sua encenação cuida do processo em jogo. Tomar partido pela expressão antes que pelo conhecimento. E a risco de cair fora de qualquer institucionalidade ou de desbordá-la, ${ }^{65}$ apostar por esta pedagogia que atuaria nas lacunas do conhecimento e cujo "processo move a expressão-pensamento colateralmente ao interior do desconhecido da situação, onde o seu efetivo potencial infinito se manifesta".66 Neste sentido e desde a perspectiva de um pragmatismo especulativo, avançar nesta pedagogia radical implica que procedamos de modo rigoroso através de técnicas como disparadoras da expressão em meio a movimentos coletivos de pensamento sem perder de vista a singularidade da(s) situação(s), sempre em processo de diagramatização como berçário para os possíveis postos em andamento pelos corpos implicados. Ali por sua vez toda expressão emergente é generativa, é disparação de disparações, ou ainda reconversão energética para o processo produtivo de pensamento-expressão que a cada movimento re-pensa e re-cria as suas técnicas. Um processo sempre aberto, poroso, desfrouxado para que outras lacunas, como potências de variaçãodesvio possam acontecer. Isto é, deixar espaços vacantes como intervalos e interstícios para que $\circ$ acontecimento possa aflorar pelo lugar menos pensado.
Expressões de expressões migrando, contaminando-se, contagiando-se, dizendo-se em variação e por outros meios. Dali que um cinema que honre realmente a expressão não possa se fixar a uma forma única, pois isso também seria clausurar o pluriverso. Fugir então todo o tempo do conhecimento, como essa "espécie de conteúdo separável do acontecimento de sua própria autoprodução expressiva". ${ }^{67}$ Em consequência nesta pedagogia radical nunca se transmite, mas pelo contrário se transduz e se transversaliza. E se insistimos em pensar com Guattari, também diremos, que é caro a ela os gestos de metamodelagem que operam justamente a partir de transversalidades. 68

Preocupar-se, então, por tudo quanto é excessivo a um modelo, a uma forma, que escapa a seu contorno e que, portanto, recusa métodos. Prestar atenção ao que se move na experiência, mas escapa a um certo quadro que demarcaria a percepção, redefinindo a cada vez a forma que $o$ encontro pode frágil e fugitivamente adquirir na tensão com as forças que o ultrapassam e excedem. Deste modo, a metamodelagem que opera por transversalidades não pararia de desafiar a normapatia, como aquilo que está no interior, no "intra" pressupondo que a experiência funciona a partir de categorias dadas. $69 \mathrm{Em}$ outras palavras, a metamodelagem

\footnotetext{
${ }^{64}$ A este respeito resultam inspiradoras as iniciativas levadas a diante pelo SenseLab da Universidade de Concordia (Canadá) e que de algum modo são apresentadas nos últimos trabalhos de Erin Manning. Cf. MANNING; MASSUMI, Thought in the act; MANNING, The minor gesture; MANNING, For a pragmatics of the useless.

65 Sobre as consequências deste desbordamento, resulta interessante a iniciativa igualmente levada adiante por Erin Manning e Brian Massumi, fundadores do SenseLab, de dar realidade a alteruniversidade nômade que é o 3E (3 Ecologies Institute), como opção não infernal para usar as palavras de Stengers, diante das limitações da institucionalidade. Para mais informações, cf. https://senselab.ca/wp2/3-ecologies/3-ecologies-institute/.

66 MASSUMI, The principle of unrest, p. 139.

67 MASSUMI, The principle of unrest, p. 140.

68 MANNING, Radical pedagogies and metamodelings of knowledge in the making.

69 MANNING, Radical pedagogies and metamodelings of knowledge in the making.
} 
cuida que a experiência seja local, mas sempre ilocalizável graças à ação de interstícios e intervalos transversais que funcionam e agem como diagramas pelos quais a experiência pode ganhar livre expressão. Uma trans-expressão que insiste em ficar no que Fred Moten e Stefano Harney 70 chamam de "estudo", onde as aprendizagens ainda podem acontecer sem cair no consumo de conhecimento e de uma certa ideia de que algo "deve ser coberto". $O$ "estudo" cuidaria do fluxo de aprendizagem, diante da vontade de discriminação do conhecimento, fazendo com que seja uma tecelagem imanente. Em vista disso uma pedagogia radical sempre começa pelo meio e até pode acontecer numa instituição, mas sempre a excede, pois o valor sempre está em formação e o que é mais valorizado (pois ali fervilha a vida) é o que excede por não ser mensurável. ${ }^{71}$ Isto é, apostar por uma "pragmática da inutilidade"72 onde 0 valor é inventado nas co-aprendizagens e se prefere não dizer o que é ou não útil, pois não podemos antecipar aonde a aprendizagem ira nos levar e o que terá valor (de eficácia) a cada dobra da situação em jogo. Não se pode prever que terá valor num tempo-ocasião que está sendo constantemente inventado e que só responde a suas relações internas e não a imposições (do tipo poder) externas. Pragmática da inutilidade como a celebração de que não sabemos para onde um pensamento pode nos levar. $O$ certo é que o caminho dessa aventura se pensa e se faz simultaneamente, como temos apostado ao longo do Azul profundo, permanecendo no mesmo barco sem cair nos falsos problemas do tipo teoria/prática. Mesmo barco, onde são inventadas novas formas de conhecimento, sempre em tom menor e para além ou aquém de qualquer método, que em meio à prática selvagem que é $\circ$ Azul profundo, podem ser chamadas de pesquisa-criação. Azul profundo, pedagogia radical em ato como "o compromisso com a criação de práticas que ponham em primeiro plano, como a aprendizagem cria seu próprio valor". 73

*

O Azul profundo, assim como a proposição do "cultivo da imagem-ovo" na sua radicalidade insistem em ser gestos menores. ${ }^{74}$ Gestos que como erva daninha brotam nos intervalos $e$ interstícios de uma universidade, onde ainda ecoa o celebre texto de William James "O polvo do doutorado", 75 como constatação da fábrica de conhecimento que a universidade já era naquele então. No entanto, como não para de acontecer ao redor do mundo, os polvos são expertos em fugir de aquários. $O$ polvo de James, embora bastante antropizado, não é a exceção e da mão do

\footnotetext{
70 HARNEY; MOTEN, The undercommons.

71 MANNING, 10 propositions for a radical pedagogy, or how to rethink value.

72 MANNING, For a pragmatics of the useless.

73 MANNING, 10 propositions for a radical pedagogy, or how to rethink value, p. 210.

74 MANNING, The Minor Gesture.

75 JAMES, The Ph.D. octopus. Resulta particularmente interessante que na sua tradução francesa o texto de James tenha sido publicado junto com o texto de Stengers Une autre science est possible! [Uma outra ciência é possível]. No volume é também incluído um estudo que faz Thierry Drumm ao texto de James intitulado Le réticulaie et le tentaculaire [O reticular e o tentacular]. Depois de tudo o advento, não só de uma outra ciência, uma "slow science", mas também de uma outra maneira de cuidarmos do pensamento, em parte depende da invenção de uma outra universidade. Uma "slow university"? Cf. STENGERS; JAMES; DRUMM, Une autre science est possible!.
} 
pensamento tentacular de Haraway, ${ }^{76}$ foge e se deixa arrastar pelo Azul profundo, onde em meio a devires reativa suas potências cefalopodiantes re-aprendendo a especular e a fabular. $\mathrm{E}$ me pergunto que passaria, se este polvo voltasse a visitar a James. Talvez, ele contaria ao filosofo a história de uma universidade por vir como usina de pensamento-expressão que diria de uma efetiva aventura das ideias. ${ }^{77}$

\section{Desvio o da obliquação diagramática}

Por fim diremos que cuidar dos ovos cinematográficos que $\circ$ Azul profundo abraçou na sua condição de berçário especulativo de mundos, sempre tem sido um gesto de grande vazão e porosidade. O Azul profundo fazendo sempre novas alianças aqui e ali, emaranhando-se em novos conglomerados de afetos que não tem parado de levar seu limite ao limite, afirmando que todo processo de criação é sempre impessoal e coletivo e deve extravasar seus próprios contornos (do contrário algo de errado tem acontecido). Por exemplo, como gestos de uma pedagogia radical que dizem de uma impossibilidade de se fechar sobre si, pois a relação sempre é primeira e, portanto, ○ Azul profundo enquanto diagrama e técnica deve ser desapego de si como metamodelagem e transversalidade problemática. Em outras palavras, no seu desdobrar como acompanhamento dos processos de criação ○ Azul profundo devem obliquação diagramática como proliferação da potência criativa do cinematógrafo cósmico que pede para vazar-se por outros corpos e meios.

Azul profundo que na sua obliquação se diz diagrama para outros mundos, se diz multiplicidade, devir-mundo, devir todo mundo ${ }^{78}$ como máximo grau de exterioridade, onde uma subjetivação das imagens pode acontecer. Feito perspectiva oblíqua, ele não para de se especular por fora de suas margens como "terceira margem". Ali, em meio a sua obliquação, quando o Azul profundo diz "eu" diz na verdade "a gente", devindo por sua vez a-gente criativo impessoal, ${ }^{79}$ múltiplo e em infinitas direções e dimensões, por justamente ser a amorfia e indeterminação equivoca necessária para se criar. Em última instancia, falamos de uma ecologia de práticas, de "emissões e disseminações" como transicionalidade na qual há possibilidade de outrar-se, de sermos refeitos e rare-feitos. Vida oblíqua se manifestado por onde o Azul profundo deixa rastos. E como último gesto, que sempre é ○ penúltimo, ○ Azul profundo outra-se e nas palavras de Clarice Lispector diz:

a vida em mim não tem $\circ$ meu nome. $E$ eu também não tenho nome, e este é o meu nome. E porque me despersonalizo a ponto de não ter o meu nome, respondo cada vez que alguém disser: eu. 80

[Então d]escobri que não tenho um dia-a-dia. É uma vida-a-vida. E que a vida é sobrenatural. ${ }^{81}$

\footnotetext{
76 HARAWAY, Staying with the trouble.

77 WHITEHEAD, Adventures of ideas.

78 DELEUZE; GUATTARI, Mil mesetas.

79 NODARI, Alterocupar-se.

80 LISPECTOR, A paixão segundo G.H., p. 112.

81 LISPECTOR, A descoberta do mundo, p. 205.
} 
Referências

A RESPEITO de ensinar e aprender. Publicado por: Agenciamento. [S. I.], 2020. 1 vídeo (3:29:18 min). Disponível em:

https://www.youtube.com/watch? $v=v l l Z$ QkZbWjE\&ab_channel=agenciamentos. Acesso em: 7 mar. 2021.

AMORIM, Antonio Carlos Rodrigues de. Diagramas para um currículo-vida. Humanidades \& Inovação, v. 7, n. 5, pp. 406-420, 2020.

BERGSON, Henri. Materia y memoria. Buenos Aires: Cactus, 2006.

CEDER, Simon. Towards a posthuman theory of educational relationality. New York: Routledge, 2020.

COCCIA, Emanuele. Metamorfoses. Rio de Janeiro: Dantes Editora, 2020.

DANOWSKI, Deborah; VIVEIROS DE CASTRO, Eduardo. Há mundo por vir? Desterro: São Paulo, SP: ISA, 2017.

DE LANDA, Manuel. Deleuze, diagrams, and the genesis of form. American Studies, v. 45, n. 1, pp. $33-41,2000$.

DEBAISE, Didier. Nature as event: the lure of the possible. Durham: Duke University Press Books, 2017.

DEBAISE, Didier; STENGERS, Isabelle. The insistence of possibles: towards a speculative pragmatism. Parse Journal, v. 7, pp. 13-19, 2017.

DELEUZE, Gilles. Diferença e repetição. Trad. Roberto Machado. São Paulo: Paz \& Terra, 2018.

DELEUZE, Gilles. Francis Bacon: lógica da sensação. Trad. José Miranda Justo. Rio de Janeiro: Zahar, 2007.

DELEUZE, Gilles. Proust e os signos. 2. ed. Trad. Roberto Machado. Rio de Janeiro: Forense, 2003.
DELEUZE, Gilles; GUATTARI, Félix. Mil mesetas: capitalismo y esquizofrenia. Valencia: Pre-Textos, 1994.

DELIGNY, Fernand. Fuvres. Paris: L'Arachnéen, 2007.

FERRAZ, Silvio. Livro das sonoridades: notas dispersas sobre composição. [S. I.]: 7 Letras, 2005.

GUIMARÃES ROSA, João. Primeiras estorias. 15. ed. Rio de Janeiro: Nova Fronteira, 2008.

HARAWAY, Donna. Staying with the trouble: making kin in the chthulucene. Durham: Duke University, 2016.

HARAWAY, Donna; GANE, Nicholas. When we have never been human, what is to be done?. Interview with Donna Haraway. Theory, Culture \& Society, v. 23, n. 7-8, pp. 135-158, 2006.

HARNEY, Stefano; MOTEN, Fred. The undercommons: fugitive planning \& black study. Wivenhoe: [s. n.], 2013.

JAMES, William. Essays in radical empiricism. Mineola: Dover Publications, 2003.

JAMES, William. The Ph.D. octopus. The Harvard Monthly, [s. I.], March, 1903.

LISPECTOR, Clarice. A descoberta do mundo. Rio de Janeiro: Rocco, 1999.

LISPECTOR, Clarice. A paixão segundo G.H. Edição crítica. 2. ed. Madrid: ALLCA XX, 1997.

MACKENZIE, Scott; MARCHESSAULT, Janine. Process cinema: handmade film in the digital age. [S. I.]: McGill-Queen's University, 2019.

MANNING, Erin. 10 propositions for a radical pedagogy, or how to rethink value. Inflexions: A Journal for research creation, v. 8, Radical Pedagogies, pp. 202-210, 2015. 
MANNING, Erin. Always more than one: individuation's dance. Durham: Duke University, 2013.

MANNING, Erin. For a pragmatics of the useless. Durham: Duke University, 2020a.

MANNING, Erin. Radical pedagogies and metamodelings of knowledge in the making. Critical Studies in Teaching and Learning, v. 8, n. SI, pp. 1-16, 2020b.

MANNING, Erin. The minor gesture. Durham: Duke University, 2016.

MANNING, Erin; MASSUMI, Brian. Thought in the act: passages in the ecology of experience. Minneapolis: University of Minnesota Press, 2014.

MASSUMI, Brian. $O$ que os animais nos ensinam sobre política. Trad. Francisco Trento e Fernanda Mello. São Paulo: n-1 edições, $2017 \mathrm{a}$.

MASSUMI, Brian. Semblance and event: activist philosophy and the occurrent arts. Cambridge: MIT, 2013.

MASSUMI, Brian. The principle of unrest: activist philosophy in the expanded field. London: Open Humanities Press, 2017b.

NODARI, Alexandre. Alterocupar-se: obliquação e transicionalidade na experiência literária. Estudos de Literatura Brasileira Contemporânea, n. 57, pp. 1-17, 2019.

NODARI, Alexandre. Lugar da escuta. In: SUB SPECIE ALTERITATIS. 10 nov. 2018. Disponível em: https://subspeciealteritatis.wordpress.co $\mathrm{m} / 2018 / 11 / 10 /$ lugar-da-escutaalexandre-nodari/. Acesso em: 7 mar. 2021.

ORLANDI, Luiz. Arrastões na imanência. Campinas: Editora Phi, 2018.

OSPINA POSSE, May Xué. La disolución del rostro o el reactivar de la bruja: tres ensayos existenciales sobre calderones contemporáneos. 2020. Tese UNICAMP, Campinas, 2020.

PACHILLA, Pablo. El mundo entero es un huevo: Ruyer, Deleuze y la genesis ideal como embriologia. In: Deleuze y las fuentes de su filosofía II. Buenos Aires: RAJGIF, pp. 43-51, 2015.

PELBART, Peter. Contra os limites da linguagem, a ética da imagem. Princípios: Revista de Filosofia (UFRN), v. 27, n. 53, pp. 135-144, 2020.

PELBART, Peter Pál. O avesso do niilismo: cartografias do esgotamento. 2. ed. São Paulo: N-1 Edições, 2017.

ROLNIK, Suely. Esferas da inssureição: notas para uma vida não cafetinada. São Paulo: N-1 Edições, 2018.

ROQUE, Tatiana. Sobre a noção de diagrama: matemática, semiótica e as lutas minoritárias. TRÁGICA: Estudos de Filosofia da Imanência, v. 8, n. 1, 2015. Disponível em: https://revistas.ufri.br/index.php/tragic a/article/view/26805. Acesso em: 6 mar. 2021.

RUYER, Raymond. Elements de psychobiologie. Paris: PUF, 1946.

SALDANHA, Rafael Mófreita. O fim do futuro: o tempo das metamorfoses - 0 que pode a filosofia?. 2018. Tese - UFRJ, Rio de Janeiro, 2018.

SANTOS, Maria Fernanda Novo dos. Habitando mundos: leituras sobre individuação. 2018. Tese - UNICAMP, Campinas, 2018.

STENGERS, Isabelle. A proposição cosmopolítica. Revista do Instituto de Estudos Brasileiros, n. 69, pp. 442-464, 2018.

STENGERS, Isabelle. Introductory notes on an ecology of practices. Cultural Studies Review, v. 11, n. 1, pp. 183-196, 2005. 
STENGERS, Isabelle. No tempo das catástrofes. São Paulo: Cosac \& Naify, 2015.

STENGERS, Isabelle. Reativar o animismo. Cadernos de Leitura, v. 62, pp. 2-15, 2017.

STENGERS, Isabelle; JAMES, William; DRUMM, Thierry. Une autre science est possible!. Paris: La Découverte, 2013.

TSING, Anna Lowenhaupt et al. (org.). Arts of living on a damaged planet: ghosts and monsters of the anthropocene. Minneapolis: [s. e.], 2017.
VIVEIROS DE CASTRO, Eduardo. Metafísicas canibais: elementos para uma antropologia pós-estrutural. São Paulo: Ubu Editora, 2018.

WHITEHEAD, Alfred North. Adventures of ideas. New York: The Free Press, 1967.

WHITEHEAD, Alfred North. Process and reality. New York: The Free Press, 1978.

Recebido em 31 de maio de 2021

Aprovado em 02 de agosto de 2021 